\title{
MINMUM INCOME PROTECTION SCHEMES IN CENTRAL AND EASTERN EUROPEAN COUNTRIES
}

\author{
ZSOLT TEMESVÁRYl
}

\begin{abstract}
This paper aims to introduce the characteristics of minimum income protection schemes in Poland, Hungary, Slovakia and the Czech Republic. Minimum social incomes incorporate all non-contributory, mostly means-tested social allowances, family supports and housing benefits which are available even to the poorest layers of society. The study first introduces the structure of minimum social protection systems in the selected countries, then assesses the amount of the related social transfers regarding three household types - single adult households, as well as single-and two-parent households with two children aged 7 and 14 years - showing the maximum amount of subsidies these households can receive. The categorization of households and social transfers was based on the 2013 SAMIP (Social Assistance and Minimum Income Protection Interim) dataset, which was revised for the 2016 MISSOC database to incorporate the newest social allowances that have been introduced since 2013 (e.g. Family 500+ in Poland and some provisions of the 2014 Hungarian welfare reform).
\end{abstract}

KEYWORDS: social allowances, social policy, poverty alleviation, minimum income, Central and Eastern Europe, welfare transfers

\section{INTRODUCTION}

The so-called social states (Dallinger 2016), featuring the Central and Eastern European (CEE) countries, cannot be compared to the traditional Western European and North American welfare state models identified by

1 Zsolt Temesváry is postdoctoral researcher at the University of Applied Sciences and Arts Northwestern Switzerland, e-mail: zsolt.temesvary@fhnw.ch. The author would like to acknowledge the support of Századvég social research institute that made the research for this paper possible. 
Esping-Andersen (1990). Due to the historical and social development of the CEE countries over the last century, the fundamental characteristics of their social policies significantly differ from the practices in Western European states (Tomka 2015). Kornai (2012) calls the Central and Eastern European countries premature welfare states, referring to the fact that although the basic institutions of welfare were also established in these countries, they were only moderately able to satisfy the social needs of people. Inglot (2008) describes the social states of the CEE countries as emergency welfare states, referring to the ad-hoc social policy interventions, a lack of predictability and strategic planning, and the poorly financed social security systems that characterize the social policies of Slovakia, Hungary, Poland and the Czech Republic.

Tomka (2015: 152) states that the contemporary social policy schemes in the CEE countries can be considered hybrid welfare models because of the region's special historical development. Before the Second World War, the Central and Eastern European countries maintained conservative welfare institutions, including a modern social security system for industrial workers, welldeveloped family policy strategies, and also a basic allowance system for the poorest groups. State-run welfare institutions were supplemented by additional private services, particularly in the area of health care and pension systems. During the four decades of communism these strong conservative pillars of social security were abolished and substituted by a soviet-like state-socialist welfare model. Bismarckian social security systems were terminated in all the socialist countries, which led to the elimination of thriving public pension funds. At the same time, the existence of poverty was denied for ideological reasons, which finally led to the elimination of social allowances. Nonetheless, one can also identify positive social policy reforms in the CEE countries in the state-socialist era. Basic medical services and pensions were extended to the formerly discriminated agricultural population. Some countries introduced generous and widespread early childhood development services and benefits for poor families. After the fall of the Soviet Union, crucial political and economic transitions (Ferge 2000; Inglot 2008) swept through the region and the World Bank provided loans to Central and Eastern European countries to alleviate the social crisis that escalated after the economic changes (Deacon et al. 2009). The World Bank often required the reform of social protection systems as a prerequisite for financial support (Rose and Mackenzie 1991; Ferge 2000; Deacon et al. 2009). These externally forced social policy reforms particularly affected pension systems and family benefits. For example, in the case of Hungary family-policy-related expenditures ran to 4 percent of GDP directly before the transition in the late 1980s. In the early 1990s, family and child-related expenditure had been reduced to 2 percent of GDP, leading - in 
practice - to the closure of kindergartens and day-nurseries, and a significant reduction in the purchasing power of family benefits. Despite the decades of state-socialist social policy and direct neo-liberal influence thereafter, the CEE countries rediscovered their conservative social policy roots relatively quickly and re-institutionalized more or less the same traditional social security-based welfare models that had prevailed in the post-war period (Inglot 2008).

The contemporary social states of CEE countries are doubtlessly based on the pre-war Bismarckian social security systems which were introduced relatively early in the region, directly after the German-speaking countries (Haggard - Kaufman 2008; Nyilas 2008). As a result, in most cases social security systems provide appropriate services and benefits in the case of unemployment, maternity, old age, disability, or accidents at work (Zombori 1994). Traditional social security systems are always supplemented by income-related, in-cash allowances which can reach even those layers of society that are not eligible for contributory social security services, or whose eligibility for these social benefits has expired.

After the 2008 economic crisis that swept through the entire region, public thinking about the direction, goals and magnitude of welfare services and support changed radically in each country. Similar to their Western European counterparts, Eastern European countries also introduced so-called workfarerelated social policy measures and deliberately reshaped their underdeveloped welfare services and transfers. Leaders in Hungary, Slovakia and Poland openly rejected western-type welfare states and stressed the importance of so-called work-based societies and activating welfare policies.

Although the basic features of work-based societies can be found in Thatcherian activating workfare policies (Simonyi 2012), the source of this kind of new social welfare paradigm originates in the neoliberal and neoconservative welfare reforms of the Anglo-Saxon countries. These reforms began with the introduction of the 1996 Personal Responsibility and Work Opportunity Act in the USA, and involved new policies sweeping across the world (Midgley 2008). These new reform concepts puts less emphasis on the social responsibility of the state towards the well-being of individuals and social groups, and highlighted the importance of self-sufficiency. The primary goal of modern social assistance systems is to re-direct beneficiaries away from passive welfare transfers towards the world of employment through targeted social policy interventions.

As a result of this new approach to welfare, the amount of income-dependent social benefits has been drastically decreased, particularly in Hungary and Poland. Social and family allowances have been tied to different behavioral conditions - such as the schooling of children in Slovakia and Hungary besides the former means-tests. Not only have the conditions of eligibility been 
significantly changed, but also the structure of available transfers. Formerly freeto-use, in-cash transfers have been gradually turned into targeted allowances only available based on the presence of children, for housing/heating, or for job-seeking purposes (Medgyesi - Scharle 2012).

Since contributory social security systems represent the foundations of welfare in work-based societies, allowance systems usually provide only poorlevel transfers, the value of which is less not only than the wages available on the labor market, but also social security benefits. As a result, one can identify a two-level structure in the area of social transfers. On the one hand, social security benefits provide a quite decent standard of living for the wealthier layers of society. On the other hand, poor people without social insurance are eligible only for low-level, means-tested social allowances (Ferge 2000). In their current form, the welfare systems of the CEE countries are more similar to the social policies of the pre-war Bismarckian conservative social states such as Germany and Austria than modern continental welfare states.

This paleo-conservativism (Ferge 2006: 59) can be seen particularly in four areas of welfare. All the CEE countries put significant emphasis on the principle of less eligibility (Zombori 1994: 122) and deliberately keep the amount of social allowances very low to motivate poor people to work and deter them from claiming allowances. The message hidden behind the distribution of poor-level allowances is that no one should receive more money from social transfers than from work-related income. Another important welfare principle in the CEE countries is the principle of subsidiarity (Zombori 1994: 118). This means that the state intervenes in the lives of families and individuals only when it is particularly necessary and unavoidable. Otherwise, individuals, families and small communities are responsible for their own well-being, including the financial and emotional support of family members in need and care for elderly people and children. Unemployment services are dominated by so-called activating policies (Simonyi 2012) which require compulsory cooperation with job centers and participation in mandatory workfare programs. For example, poor people can easily lose their eligibility to social allowances in Hungary if they do not undertake at least 30 days of public work a year. In the field of family benefits, working parents can obtain a much higher social income through social security benefits and the generous tax systems than poor parents who generally only receive means-tested child-related allowances. 


\section{SOCIAL ALLOWANCES IN THE CEE COUNTRIES}

It is important to highlight that although the regular housing and child-related social allowances introduced below serve as the foundation of the analyzed social welfare systems, they are not the only source of income poor people can rely on. These basic allowances are available to all those (including the poorest) who belong to the given risk groups, but beneficiaries may also be eligible for those additional transfers for which they meet conditions of eligibility (e.g. willingness to search for a job).

\section{Poland}

Social allowances in Poland are non-contributory benefits for people in need that incorporate various in-cash and in-kind transfers. Families and individuals whose monthly income is below the income threshold are eligible for the allowances. In certain cases, in-cash allowances can be combined with some social security benefits (e.g. pensions and unemployment benefits).

People with low income or a reduced capacity to work because of their age or disability are eligible for a Regular Social Allowance (Zasitek Staty). The income threshold of the transfer is 634 PLN (150 EUR) per capita for single-adult households and 514 PLN (121 EUR) for families. Elderly people ineligible for a social security-based pension and people unable to work because of disability or permanent illness can also receive the standard allowance if the social security agency verifies their eligibility. The amount of benefit depends on the number of family members and the income of the household, but must be within the range of 30 PLN (6.66 EUR) to 604 PLN (142 EUR) a month. A Regular Social Allowance can also be provided to unemployed persons whose social securitybased unemployment benefit has expired. ${ }^{2}$

Social assistance centers can provide Temporary Allowance (Zasitek Okresowy) for poor people without any income, or for those whose income is below the poverty threshold and do not have enough cash assets to take care of their families. The target group for the Temporary Allowance is unemployed people without social security benefits and people with serious disabilities. Temporary Allowance can be combined with other contributory social security benefits, but the amount of these benefits is deducted from the transfer. The

2 http://www.infor.pl/prawo/pomoc-spoleczna/zasilki/321338,Kiedy-przysluguje-zasilek-staly.html (accessed 3 January, 2017) 
primary goal of the Temporary Allowance is to secure the minimum living costs for people in need during times of unemployment, disability, or illness. The amount of the allowance is the difference between the legally declared maximum value of the benefit and the actual income of beneficiaries, but cannot be less than 20 EUR or more than 418 PLN (99 EUR). Beneficiaries are allowed to apply for temporary allowances only once every two years. If an employer employs a Temporary Allowance beneficiary, the employee can keep the allowance in the first two months of employment. This option makes the transition between unemployment and employment easier and provides extra money for poor people so they are able to cover increased costs, such as those of traveling and clothing, in the first period of employment. Authorities assess eligibility for the allowance as well as the amount of the transfer on a case-bycase basis. After the expiration of the two-year support period, beneficiaries can re-apply for the allowance if there has been no improvement in the household's financial situation (MISSOC 2016).

The Special Social Allowance (Zasitek specjalny) can be transferred to families and individuals whose social needs are caused by special life circumstances such as sudden illness, natural disaster or the death of a family member. The Special Allowance is a lump-sum transfer always determined on a case-by-case basis. A targeted form of Special Allowance is available for homeless people to help them cover the costs of their medical care. Eligibility for the Special Allowance is evaluated by local municipalities and depends on applicants' financial conditions. ${ }^{3}$ The income threshold for the Special Allowance is 634 PLN (140.89 EUR) for single households and 514 PLN (114.22 EUR) for families. ${ }^{4}$

The most important family-related allowance of Polish social policy is the Family Allowance (Zasiłek rodzinny) which covers more than two million children in the country. The Family Allowance is paid until the child's eighteenth birthday, or longer if they attend school or have a disability. The amount of the Family Allowance depends on the child's age. A young child under the age of five can receive 95 PLN (21.11 EUR), a child aged 5-18 years 118 PLN (26.22 EUR), while young people aged 19-23 years can get 129 PLN (28.67 EUR). The Polish government introduced the "Zloty for zloty" program in 2017 that also enabled low-income families earning a little above the income threshold to receive the Family Allowance. According to the reform, families whose monthly income is higher than the income threshold of the Family Allowance - at least by 20 PLN

\footnotetext{
3 http://ops.pl/2016/04/kiedy-i-komu-przysluguje-zasilek-celowy/ (accessed 12 January, 2017) $4 \mathrm{http}: / /$ www.mops.pila.pl/swiadczenia.html (accessed 12 January, 2017)

5 http://www.mpips.gov.pl/aktualnosci-wszystkie/art,5538,7217, wyzsze-swiadczenia-rodzinne-iprogi-dochodowe.html?serwis=1 (accessed 11 December, 2016)
} 
(4.72 EUR) - can receive a partial transfer. In this case, the full amount of the allowance is reduced by the difference between the family's income and the official income threshold of the Family Allowance. The official income threshold of the transfer is 674 PLN (159 EUR) per capita or 764 PLN (180 EUR) in the case of a disabled child (MISSOC 2016).

A new element of the Polish family policy is the so-called Family 500+ (Rodzina 500+) program. All families raising two or more children, as well as poor families with one child, are eligible for the benefit. The goal of the allowance is to support childbearing, to reduce the financial burdens of large families, and to support poor families with children directly. The introduction of the transfer is underpinned by the fact that Poland has the lowest fertility rate in the EU (1.3 children per woman) and that the poverty rate of families with more than three children is twice as high ( 36 percent) as the average poverty rate in the country. The amount of the transfer is 500 PLN (114 EUR) which all families with two or more children are eligible for, and even one-child families are eligible if their monthly income is less than 800 PLN (182 EUR) per capita. Family 500+ is paid until the eighteenth birthday of the child. The program is maintained by local municipalities which can also pay it in-kind where appropriate. According to the calculations of the Polish government, the yearly cost of the program is approximately five million euros, and the number of participants is 3.7 million (Sowa 2016: 2).

A Supplement for Raising a Child Alone is a transfer for single mothers or fathers who cannot rely on any financial support from their partner due to their death or related financial problems. ${ }^{6}$ The amount of the transfer is 185 PLN (42 EUR) per child, but cannot exceed 370 PLN (84 EUR) per family (MISSOC 2016). The monthly income threshold of the supplement is 725 PLN (171 EUR) per capita.

\section{Czech Republic}

In the Czech Republic, the entire system of social allowances belongs to a unified state-run welfare program called Social Assistance in Material Need (SAMN, Systém pomoci v hmotné nouzi). This large program incorporates three forms of in-cash benefits: Allowance for Living (Prispevek na živobyti), Supplement for Housing (Doplatek na bydleni) and Extraordinary Immediate

6 http://www.infor.pl/prawo/zasilki/zasilek-rodzinny/276615,Kto-moze-otrzymac-dodatek-z-tytulusamotnego-wychowania-dziecka.html (accessed 11 December, 2016) 
Assistance (Mimořádná okamžitá pomoc). All social allowances included in this system are means-tested, non-contributory and maintained by the regional labor offices. Poor people participating in the SAMN program must prove their willingness to work, so they are required to register at the labor offices as jobseekers, accept any kind of jobs, and participate in alternative projects such as public work, training, and counselling (European Commission 2013a: 27).

People who are unable to maintain their living conditions on their own are eligible for the Living Allowance. The allowance provides support for everyday necessities such as food, clothes and traveling, excluding housing-related expenditures. The amount of the allowance depends on the income level and other social conditions of beneficiaries. The Czech government has introduced an indicator called Living- and Subsistence Minimum (Zákon o životním a existenčnim minimu) which determines the income eligibility of the Living Allowance and other social transfers. The amount of the Living and Subsistence Minimum is 3410 CZK (126 EUR) for a single-adult household, an additional 3140 CZK (116 EUR) for a second adult, an additional 2830 CZK (105 EUR) for a child, and 1740 CZK (64 EUR) for children under six years of age. Since the amount of the Living Allowance depends on family status, the number of family members and the economic condition of the region where the family lives, calculation of the exact provision is quite difficult. The amount of the Living Allowance is, for instance, 3410 CZK (136.4 EUR) for a single-person household in Prague, while a two-parents-and-two-child household living in the countryside receives 9850 CZK (378 EUR), from which family allowances are deducted.

A Housing Allowance (Doplatek na bydleni) is provided to individuals and families who are unable to maintain their household without the governmental rent- and overhead subsidy. The amount of the transfer is calculated so as to fill the gap between Justified Housing Costs and the real income of the family that can be applied towards housing purposes. Justified Housing Costs are legally determined and include rental- and overhead costs as well as some other housing-related regular expenditures. Households for whom 30 percent of their net monthly income is not enough to cover the Justified Housing Costs calculated for the given household-type are eligible for the housing subsidy. Calculation of Housing Allowance considers the number of household members, the economic characteristics of the village or town where the apartment can be found, as well as the property relations (owned or rented apartment). The amount of the Housing Allowance is - for example - 3600 CZK (144 EUR) in the case of a two-person household in Prague where a couple pays 4500 CZK

7 http://www.penize.cz/kalkulacky/prispevek-na-zivobyti\#prisZiv (accessed 07 January, 2017)

CORVINUS JOURNAL OF SOCIOLOGY AND SOCIAL POLICY VOL. 9 (2018) 2 
(167 EUR) for the apartment in the form of rent and/or overheads, and whose monthly income is 20000 CZK (740 EUR). ${ }^{8}$

The third pillar of the Czech social allowance system is Extraordinary Immediate Assistance, which is provided by local municipalities to alleviate temporary financial problems. The calculation of the allowance is always based on individual life situations and is not predefined (MISSOC 2016).

Child Allowance (Pŕídavek na ditě) is available for families raising at least one child under the age of 15 years. The supporting period of Child Allowance can be extended to the twenty-sixth birthday of the child if they attend school or have serious medical problems. Families whose income is less than 240 percent of the Living- and Subsistence Minimum are eligible for Child Allowance. The amount of this allowance is $500 \mathrm{CZK}$ (19 EUR) for children under six years of age, 610 CZK (23 EUR) for children aged 6-15 years, and 700 CZK (27 EUR) for children aged 15-26 years. The allowance is paid to the parents until the child's eighteenth birthday. After coming of age, young adults can directly receive the transfer.

\section{Slovakia}

In the Slovak Republic, the system of social allowances belongs to the national Labor, Social Affairs and Family Office whose regional agencies are responsible for the assessment of eligibility and the payment of allowances. Temporary assistance provisions are organized and financed by local municipalities (European Commission 2013b: 35). Similar to the Czech Republic, the Slovak social assistance system also applies a so-called Subsistence Minimum (Životné minimum) to determine eligibility for social allowances. The amount of the Subsistence Minimum expresses the basic costs of living that are generally accepted in Slovak society, so it includes one warm meal per day as well as basic clothing and housing costs (MISSOC 2016). The amount of the Subsistence Minimum is 198.9 EUR for a single-person household, 138.19 EUR for each additional adult and 90.42 EUR for children under the age of eighteen. ${ }^{9}$

The Slovak social assistance system incorporates three categories of welfare transfers. The most important one is Assistance in Material Need (Pomoc v

8 http://www.penize.cz/davky-v-hmotne-nouzi/309216-doplatek-na-bydleni-2016-pravidla-avypocet (accessed 05 January, 2017)

9 https://www.podnikajte.sk/dane-a-uctovnictvo/c/2710/category/dane-a-uctovnictvo/article/sumazivotneho-minima-2016-2017.xhtml (accessed 20 December, 2016) 
hmotnej núdzi), a regular form of social support available to all persons and families in need. The second category of the allowance system is a needsbased welfare package that incorporates various smaller in-cash transfers such as Protecting Allowance (Ochranný príspevok), Activation Allowance (Aktivačný príspevok), Housing Benefit (Príspevok na bývanie) and Allowance for a Dependent Child (Príspevok na nezaopatrené diet'a). Eligibility to these special allowances always depends on the living conditions of families such as the number of children and/or disabled or seriously ill persons in the family, housing conditions, and the adult's job-seeking activity. The third pillar of the allowance system is a lump-sum, one-off benefit (Jednorazová dávka) provided by local municipalities only in the case of special needs.

Assistance in Material Need is available for individuals and families whose monthly income is lower than the amount of subsistence minimum. The amount of this allowance depends on the size of the family. Assistance in Material Need is a supplementary social transfer that supplements the monthly income of poor households up to a ceiling determined in the social act. Thus, the actual amount is the difference between the transfer's official maximum level and the aggregated net income of the family. The highest possible amount of Assistance in Material Need is 61.60 EUR for one-person households, 117.20 for single-parent households with 1-4 children, 107.1 EUR for a couple without children, 160.4 EUR for a couple with 1-4 children, 171.2 EUR for single parents with more than five children, and 216.1 EUR for couples with more than five children..$^{10}$ The period of support of the benefit is not limited; it is paid as long as the household is eligible (MISSOC 2016).

Assistance in Material Need is supplemented by other special needs-based social transfers, two of which belong to the category of guaranteed minimum resources that this paper examines. The Allowance for a Dependent Child is transferred to poor families earning under the subsistence minimum whose children (aged 6-16) attend public education. The amount of the allowance is 17.2 EUR per child. ${ }^{11}$ A Housing Allowance is available to households - without any overhead or rent-related debt - for whom the payment of housing costs causes problems. In addition, beneficiaries must have a long-term rental agreement or must be the owners of the property. The amount of the Housing Allowance is 55.8 EUR for a single-person household and 89.20 EUR for a household with two or more members. The Protecting Allowance is a social transfer available for the

10 https:/www.employment.gov.sk/sk/rodina-socialna-pomoc/hmotna-nudza/vyska-pomocihmotnej-nudzi/davka-hmotnej-nudzi.html (accessed 5 January, 2017)

$11 \mathrm{https}$ //www.employment.gov.sk/sk/rodina-socialna-pomoc/hmotna-nudza/davky-hmotnej-nudzi/ prispevok-byvanie/ (accessed 10 January, 2017) 
most vulnerable social groups, such as elderly people without pension eligibility, people with reduced capacity to work and single mothers raising infants. The amount of the transfer varies between 13.5 EUR (for single mothers) and 63.7 EUR (for the elderly without pension) according to the special needs of the risk group. The lump-sum Special Benefit is maintained by local municipalities and provided to families or individuals in threatening living situations. The exact amount of this Special Allowance is regulated in local decrees, but cannot be higher than 300 percent of the subsistence minimum (596.7 EUR). ${ }^{12}$

The most important minimum income resource for poor families with children is Child Benefit (Prídavokna dieta), which is a regular non-contributory monthly transfer. The amount of the Child Benefit is 23.52 EUR per child. Unemployed parents participating in job-seeking activities such as public work, counselling or education receive a higher amount of benefit (54 EUR for the first and 42 EUR for additional children) during periods of active job-seeking. If grandparents are the guardians of a child, they receive an additional 11.3 EUR per month. Child Benefit is paid until the end of compulsory education, until the age of sixteen. The supporting period can be extended until the twenty-fifth birthday of the child if they attend school, are disabled or seriously ill. ${ }^{13}$

\section{Hungary}

The system of social allowances was fundamentally reformed in Hungary in 2014. As a result of the country's social policy reform, the majority of social allowances were delegated from local municipalities to micro regions. Former elements of the allowance system such as the Housing Allowance, Temporary Allowance and Debt Management Services have been entirely eliminated or re-organized under new names. The government's aim behind the welfare reform was to orient poor people away from passive welfare transfers towards active workfare services. The most important such workfare service is the public work program that gives work to almost 350 000 poor people in Hungary and thus provides them with a higher standard of living compared to that which they would have being unemployed and living solely from social allowances. Through participation in public work

12 https://www.employment.gov.sk/sk/rodina-socialna-pomoc/hmotna-nudza/davky-hmotnej-nudzi/ jednorazova-davka-hmotnej-nudzi/ (accessed 10 January, 2017)

13 https://www.employment.gov.sk/sk/rodina-socialna-pomoc/podpora-rodinam-detmi/penaznapomoc/pridavok-dieta/ (accessed 13 January, 2017) 
programs, people can receive twice as much income as they would living from social allowances (Mód et al. 2016: 56). Only those people are eligible for the means-tested social allowances who demonstrate a willingness to work, participate in job-seeking activities, or are otherwise unable to maintain a basic standard of living (Mózer et al. 2015).

Benefit for Persons of Active Age (aktív korúak ellátása) is a non-contributory social allowance financed from the state budget. The transfer is available to unemployed people without social security-related benefits, to people with reduced capacity to work, and to people living with a serious disability. The income requirement associated with the transfer is that the monthly income of beneficiaries cannot be higher than 90 percent of the pension minimum. Only one adult person per household can receive the allowance, and all beneficiaries must cooperate with the labor and rehabilitation authorities. Benefit for Persons of Active Age has two elements: Benefit for People Suffering from Health Problems or Taking Care of a Child (egészségkárosodási és gyermekfelügyeleti támogatás), and Employment Substituting Benefit (foglalkoztatást helyettesitö támogatás). The first transfer is available to households caring for a disabled family member, as well as for parents raising a child under the age of 14 years and unable to secure the day-care of the child. ${ }^{14}$ The maximum amount of the benefit is 90 percent of the public workers' wage (161.2 EUR). The monthly average number of beneficiaries was 160858 and the yearly cost of the transfer totaled 44 billion HUF (145.2 million EUR) in 2014 (KSH 2015). Employment Substituting Benefit is available to able-bodied, active-age and unemployed people living in poverty. The amount of transfer is 80 per cent of the pension minimum (22 $800 \mathrm{HUF}$, 75.24 EUR). Beneficiaries are required to participate in the public work program of the government or other job-related activities (e.g. voluntary work) for at least 30 days a year and cooperate with the regional labor offices.

People with special and immediate needs can receive Local Benefit (települési támogatás) which is controlled and provided by municipalities. The national social act determines only the general frameworks of Local Benefit so municipalities reserve the right to specify the conditions of eligibility in their own decrees. According to the social act, Local Benefit can be given in the case of housing-related problems, to support schooling, and to contribute to the medical costs of ill or disabled people. The amount of local benefits cannot be higher than the pension minimum (28 500 HUF, 94.05 EUR).

Family Allowance (családi pótlék) is a non-means-tested transfer available to all families raising children in Hungary. Family allowance is the most

14 http://net.jogtar.hu/jr/gen/hjegy_doc.cgi?docid=99300003.TV (accessed 13 January, 2017) 
important income source for poor families. It makes up 25 percent of single parent households' income, and 15 percent of two-parent households' income on average (Kovács - Pillók 2014). Family allowance includes two elements: Child Raising Allowance (gyermeknevelési támogatás) for children aged 0-6 years and Schooling Allowance (iskoláztatási támogatás) for children aged 6-16 years. Family Allowance is available up to the age of 20 if the child continues full-time education, or to the age of 23 if the child has special needs. The amount of the allowance varies according to the number and health status of children as well as the family status of parents. The basic amount of Family Allowance is 12200 HUF (40.26 EUR) for a single child, 13300 HUF (43.89 EUR) for two, and 16 000 HUF (52.8 EUR) for three or more children. Single parents and parents raising seriously ill or disabled children can receive a higher amount, up to 25 900 HUF (85.47 EUR) per child. Households receiving Family Allowance are required to take care of the schooling or regular kindergarten attendance of their children. If the child misses more than 50 classes a year, Schooling Allowance is suspended for three months. If small children, miss more than 20 days of kindergarten, the notary can temporarily suspend the Child Raising Allowance. Family Allowance was transferred in support of 1.8 million children (1.1 million families) in 2015 (KSH 2015).

Poor families raising children are also eligible for the Regular Child Protection Allowance ( $R G Y K$, rendszeres gyermekvédelmi kedvezmény). This allowance is available to families whose monthly income per capita is below 140 percent of the minimum pension, while in the case of single parents this proportion is 130 percent. The allowance is provided for the period of compulsory education and can be extended until the twenty-fifth birthday of the child if they attend higher education. The amount of the allowance is 22 percent of the minimum pension (6720 HUF, 20.69 EUR).

\section{VALUE OF THE ANALYZED SOCIAL ALLOWANCES}

This paper considers those non-contributory and needs-based social transfers as regular in-cash allowances which are basically available to all poor people regardless of the number of years spent at work or the amount of social contribution or tax previously paid to the state. These minimum transfers represent the bottom level of welfare systems, and even the neediest layers of society can benefit from them merely according to their rights as citizens and unfavorable social status. In his "three-storey house" model, Offe (2006: 4244) describes these minimum in-cash transfers as the imaginary "cellar of the 
welfare states," in which those social transfers can be found that provide the possibly lowest but socially still acceptable standard of living for poor people in a given community, and on which the more developed social security benefits and services can be built up.

Regular social allowances are probably the most widespread transfers in the social policies of the CEE countries that are - to some extent - available to all people with income-related poverty, regardless of housing conditions and the number of children, meaning that even childless couples and single households can receive these kinds of support. Naturally, the amount of regular allowances may be higher in the case of families because legislators can acknowledge children as additional consumption units in the household, or through the rights of children adult beneficiaries are classified into another supporting category. For example, in Hungary adults raising children can receive a larger regular social allowance than childless ones, through which the state indirectly acknowledges the augmented burdens of child raising. In this case, the allowance surplus due to the existence of children cannot be separately considered as a family allowance, since it is paid to adults in their own right, not directly after their children. Sometimes it is hard to define which allowances should be classified into the category of regular basic social allowances, and which ones belong rather to family support systems. In general, family support is regulated by family law and social allowances (even if they are child-related) by social law. In more sophisticated social systems, many forms of social allowances are deducted from family allowances, or vice versa, and parents are not eligible to receive duplicate transfers simultaneously both according to their own and their children's rights. Although regular allowances are the basis of all minimum social protection schemes, they can occasionally be supplemented by other "low threshold" welfare transfers such as child allowance and housing allowance.

The diagram below shows that - due to the additional child allowances all CEE countries provide significantly higher benefits to poor households with children compared to single-adult households. Apart from Slovakia, where the amount of social allowances is higher, the other three countries under analysis provide a more or less similar value of support to single-adult households. Single-parent households can receive more or less the same support in all countries. Slovakia and the Czech Republic provide the most money to twoparents-and-two-children households. One can also see from the figure that Hungary gives the least support to all household types in the form of incomesupplementing social allowances, and Hungary is also the only country where there is no significant difference between the highest available allowances for single- and two-parent household types. 
Figure 1 Minimum amount of regular social allowances in CEE countries in three household types (2016) (EUR)

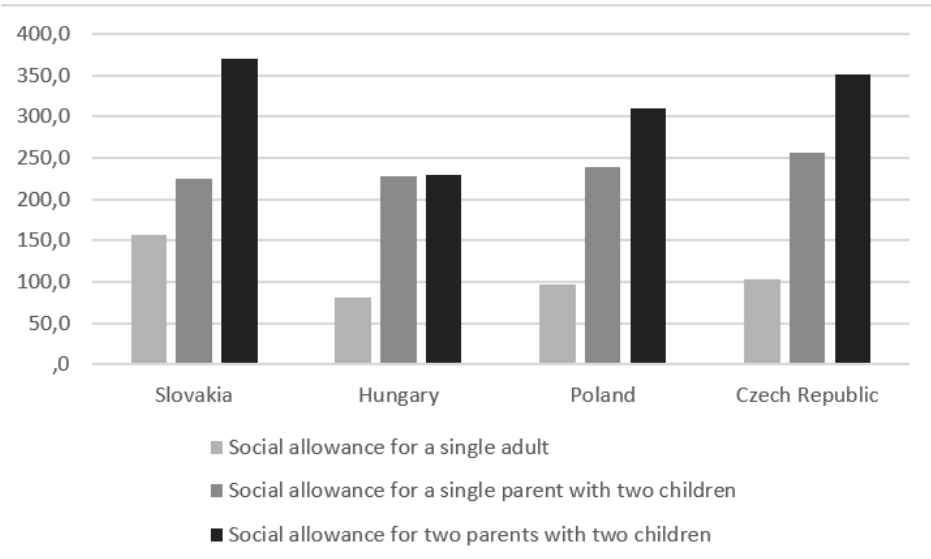

Source: SAMIP (2013) and MISSOC (2016), with the author's corrections

The category of family allowances includes all in-cash benefits available to families only due to the rights of children. Thus, this category incorporates all non-contributory child care allowances, child-raising related support, as well as schooling allowances which can be either universal (e.g. in Hungary) or meanstested (e.g. in Slovakia). The majority of family allowances are deducted from the general social allowance in the Czech Republic and Poland if the family is eligible for both types of allowances. Therefore, the original SAMIP database includes a zero value for family benefits in the aggregation of minimum income transfers in the case of these countries to avoid double-counting. To show the real value of these family-related forms of support, I apply this deduction only at the stage of the final aggregation of minimum transfers and show the actual value of family allowances in the graph below. In contrast, the general Family Allowance (családi pótlék) of Hungary is not counted as deductible income, therefore it represents an income surplus for all families - including poor households who are raising children. The new Family 500+ program of Poland significantly increased the amount of family support available to poor households in 2016.

Due to the Family 500+ program, Polish single- and two-parent households can receive the most money after their children among the countries under analysis. Hungary provides a little more support for single-parent households compared to two-parent families, since the amount of the Family Allowance is slightly higher for single parents. The relevance of separated and targeted 
family-related support in the Czech and Slovak welfare systems is relatively small since in these countries other benefits - such as housing allowance and regular social allowance - are already calculated on a family basis.

Figure 2 Amount of family allowances in CEE countries (2016) (EUR)

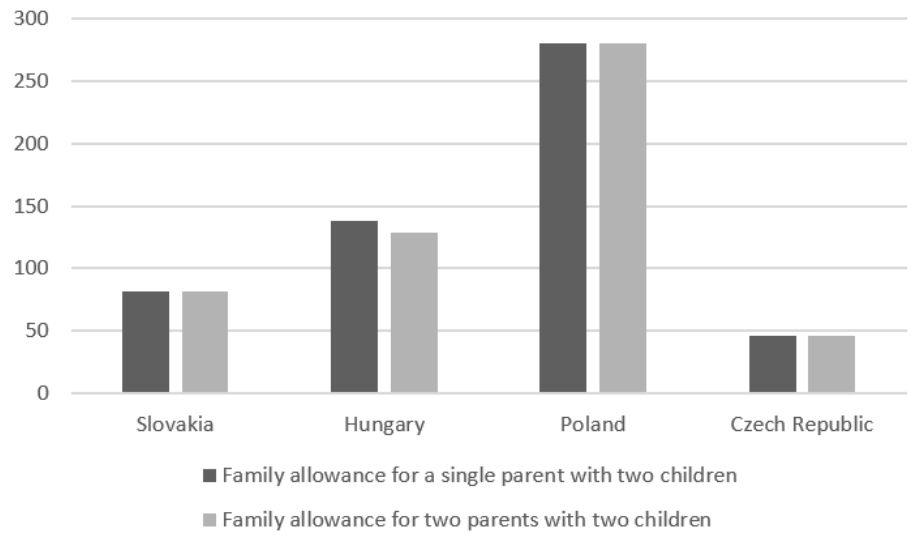

Source: SAMIP (2013) and MISSOC (2016) with the author's corrections

The category of housing allowances incorporates the different forms of social support provided for heating, rent and other housing-related expenditures. Only Slovakia and the Czech Republic maintain targeted housing allowance programs, while Poland has never provided direct housing support for people in need. The Polish government rather supports housing indirectly, in the form of targeted family benefits and regular social allowances. Hungary canceled its Housing Allowance program in the 2014 welfare reform, and introduced general and universal Overhead Support for all citizens, as well as municipality-run Social Firewood Support, an in-kind allowance available only to the neediest families.

The amount of Housing Allowance is significantly higher in the Czech Republic compared to Slovakia for all household types. The Slovak housing allowance is a fixed-value transfer which is differentiated according to the number of family members. Czech housing support uses a more sophisticated allocation system. In the calculation of the allowance, the income of the family, the number of family members, the regional characteristics of housing, the family status and other factors are equally considered. As a result, the amount of Housing Allowance proportionally increases with the number of household members in the Czech Republic. 
Figure 3 Housing allowance in Slovakia and the Czech Republic (2016) (EUR)

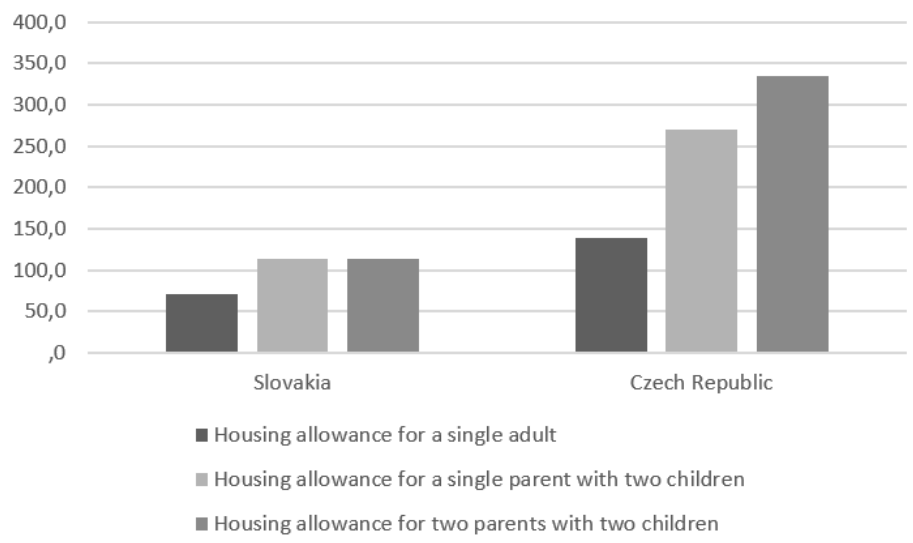

Source: SAMIP (2013) and MISSOC (2016) with the author's corrections

Examination of the aggregated values of the above-detailed social transfers belonging to the minimum income schemes shows that - despite relatively generous family allowances - Poland and Hungary provide significantly lower value transfers to poor families than the other two CEE countries. Due to its generous housing allowance system, the Czech Republic offers the highest level of transfers considering all elements of the national minimum protection schemes. It can also be seen from the graph that Hungary is the only country where there is no real difference between the allowances available to singleparent- and two-parent households, since the general social allowance is available only to one family member. The amount of the Hungarian and Polish social allowance significantly lags behind the benefits available to poor families in Slovakia and the Czech Republic.

Finally, it is worthwhile comparing the amount of social benefits with the net average wages in the countries under analysis to reveal the relative value of transfers in the given economic environment. Since the net average wage is more or less similar in Poland, Slovakia, Hungary and the Czech Republic, this comparison does not significantly modify the differences that can be seen in the euro-based calculation provided above. Net average wages are lowest in Hungary (613 EUR), therefore the relative value of the aggregated Hungarian transfers is slightly closer to the other three countries. The diagram below shows that Poland and Hungary significantly lag behind the Czech Republic and Slovakia in terms of not only the absolute but also the relative value of minimum social transfers. 
Figure 4 Amount of all available social allowances in CEE countries (2016) (EUR)

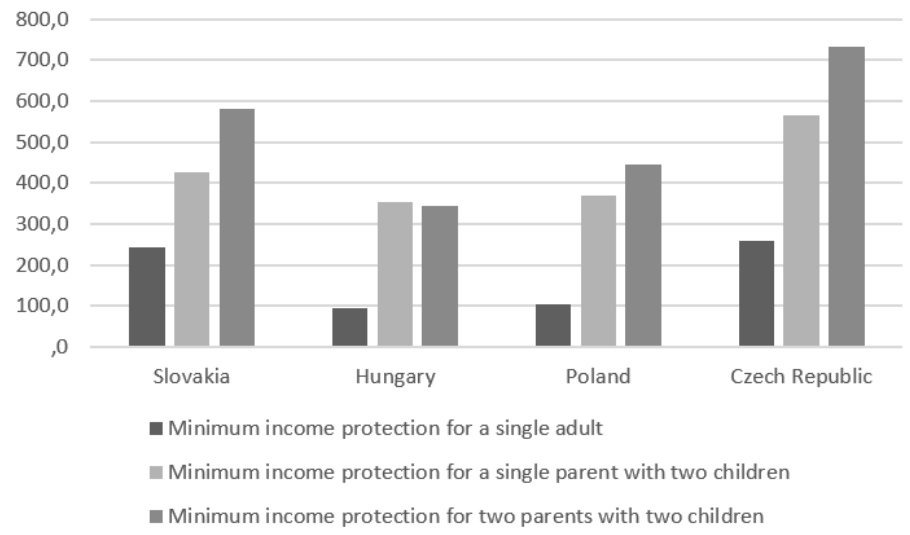

Source: SAMIP (2013) and MISSOC (2016) with the author's corrections

Figure 5 Amount of all available social allowances in CEE countries compared to monthly net average wage (2016) (\%)

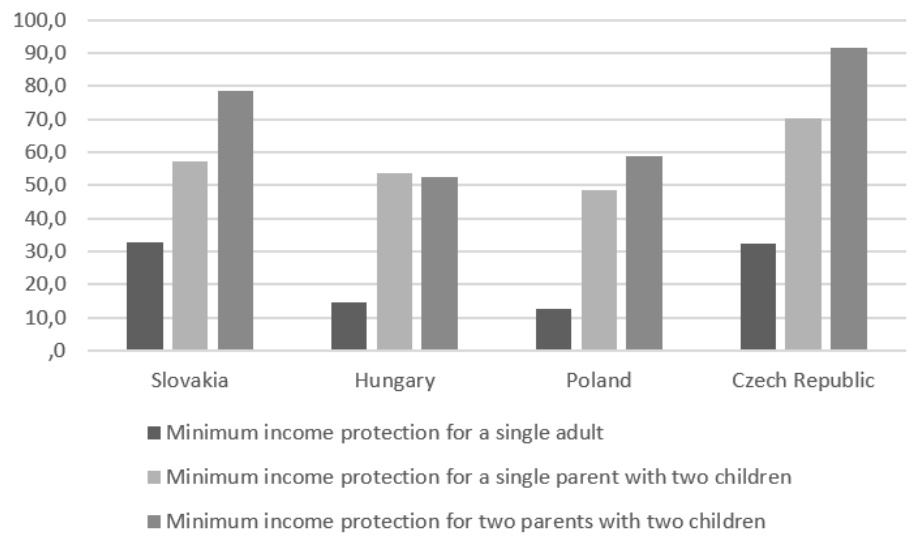

Source: SAMIP (2013) and MISSOC (2016) with the author's corrections 


\section{SUMMARY}

The paper was written to introduce and compare the minimum social protection systems in Hungary, Poland, Slovakia and the Czech Republic. The study examined those non-contributory social, child welfare and housing allowances that are available even to the lowest strata of society based on their financial needs. Although the majority of these social allowances are already means-tested, the national governments occasionally define behavior-related conditions too, such as participation in public work programs and compulsory schooling of children.

The structure of minimum protection systems was analyzed among three allowance categories: (1) regular social allowances, (2) housing support, and (3) family allowances, in three household types: single-adult-, singleparent-, and two-parent households. The structure and emphases of minimum allowance schemes are quite different in the four CEE countries. Poland and Hungary put significant emphasis on targeted family- and child allowances, do not maintain a differentiated system of housing support, and provide only a moderate amount of money in the form of general social allowances. In contrast, Slovakia, and particularly the Czech Republic, maintain a generous housing allowance system, which is highly sensitive to the number of children and other family-related conditions, so these countries pay significantly less direct child allowance compared to Poland and Hungary.

Examination of the aggregated values of minimum protection transfers shows that Slovakia and the Czech Republic provide significantly higher value transfers to all household types than Hungary and Poland.

\section{REFERENCES}

Dallinger, Ursula (2016), Sozialpolitik im internationalen Vergleich, Konstanz, UVK Verlagsgesellschaft

Deacon, Bob - Michelle Hulse - Paul Stubbs (2009), "Globalism and the study of social policy," in: Yeates, Nicola - Chris Holden ed., The Global Social Policy Reader, Bristol, The Policy Press, pp. 5-27.

Esping-Andersen, Gösta (1990), Three Ways of Welfare Capitalism, Cambridge, Polity Press

European Commission (2013a), "Your social security rights in the Czech Republic", Brussels, European Commission, pp. 1-30. 
http://ec.europa.eu/employment_social/empl_portal/SSRinEU/Your\%20 social $\% 20$ security $\% 20$ rights $\% 20$ in $\% 20$ Czech\%20Republic_en.pdf (accessed 02. February 2017)

European Commission (2013b), "Your social security rights in Slovakia", Brussels, European Commission, pp. 1-38. http://ec.europa.eu/employment social/empl_portal/SSRinEU/Your\%20social\%20securit \%20righ ts $\% 20$ in\%20Slovakia_en.pdf (accessed 02. February 2017)

Ferge Zsuzsa (2000), Elszabaduló egyenlötlenségek [Unleashed Inequalities], Budapest, Hilscher Rezső Szociálpolitikai Egyesület

Ferge Zsuzsa (2006) “...Mindig más történik: a jóléti állam lehetséges jövőképei Magyarországon 2015-ig" [...Always else happens: Possible prospects of the welfare state in Hungary until 2015], in. Tausz Katalin ed., A társadalmi kohézió erősítése [Reinforcing Social Cohesion], Budapest, Új Mandátum Könyvkiadó, pp. 54-67.

Haggard, Stephan - Robert R. Kaufman (2008), Development, Democracy and Welfare States: Latin America, East Asia and Eastern Europe, Princeton, University Press

Inglot, Tomasz (2008), Welfare States in East Central Europe, Cambridge, University Press

Kornai János (2012), A szocialista rendszer [The Socialist System], Budapest, Pesti Kalligram

Kovács Szilvia - Pillók Péter (2014), “Az állami transzferek szerepe a széthulló családokban" [The role of social transfers in broken families], Kapocs Vol. 13, No 1 (60), pp. 40-49.

KSH, Központi Statisztikai Hivatal (2015), “A családtámogatási és gyermekgondozási ellátások" [Family- and child care supports], Budapest, KSH, https://www.ksh.hu/docs/hun/xstadat/xstadat_eves/i_fsp006.html (accessed: 11. January 2017)

Medgyesi Márton - Scharle Ágota (2012), "Mobility with joint forces: The decreasing of deep poverty with conditional transfers", Budapest, Patriotism and Progress Public Policy Foundation, http://old.tarki.hu/en/news/2012/ items/20120329_hesh_paper_summary_eng_sent.pdf (accessed: 28. May 2018)

Midgley, James (2008), "Welfare Reform in the United States: Implications for British Social Policy (with Commentaries by Kitty Stewart, David Piachaud and Howard Glennerstein)", LSE STICERD Research Paper No. CASE131, https://ssrn.com/abstract=1159362 (accessed 07. February 2018)

MISSOC (2016), "Comparative tables database", http://www.missoc.org/ INFORMATIONBASE/COMPARATIVETABLES/MISSOCDA ABASE/ comparativeTableSearch.jsp (accessed 15. January 2017) 
Mód Péter - Gál-Schneider Barbara - Ignits Györgyi - Varga Lívia (2016), "Beszámoló a 2015. évi közfoglalkoztatásról" [Report on the 2015 workfare programme], Budapest, Belügyminisztérium, https://kozfoglalkoztatas. kormany.hu/download/2/b1/91000/Besz $\% \mathrm{C} 3 \% \mathrm{~A} 1 \mathrm{~mol} \% \mathrm{C} 3 \% \mathrm{~B} 3 \% \quad 20 \mathrm{a} \% 20$ 2015\%20\%C3\%A9vi\%20k\%C3\%B6zfoglalkoztat\%C3\%A1sr\%C3\%B31.pdf (accessed: 28. May 2018)

Mózer Péter - Tausz Katalin - Varga Attila (2015), “A segélyezési rendszer változásai" [Changes in the System of Social Allowances], Esély Vol. 26, No 3, pp. 43-66.

Nyilas Mihály (2008), Szociálpolitika-történeti szöveggyüjtemény [Coursebook on the History of Social Policy], Budapest, Hilscher Rezső Szociálpolitikai Egyesület

Offe, Claus (2006), “Szociális védelem szupranacionális összefüggésben: Az európai integráció és az „Európai Szociális Modell” jövője” [Social protection in a supranational context: European integration and the fates of the European Social Model], Esély Vol. 17, No 3, pp. 30-60.

Rose, Richard - W. J. M Mackenzie (1991), "Comparing Forms of Comparative Analysis", Political Studies Vol. 39, No 3, pp. 446-462.

Simonyi Ágnes (2012), “Aktiválás - foglalkoztatás- és szociálpolitikák eszközeinek és intézményeinek összehangolása a fejlett országokban" [Activation - the reconciliation of labour- and social policies in the developed countries], Esély Vol. 23, No. 2, pp. 66-99.

Sowa, Agnieszka (2016), "Family 500+: A new family income-supporting benefit in Poland", ESPN Flash Report No. 45, ec.europa.eu/social/ BlobServlet?docId=16077\&langId=en (accessed 15 January 2017)

SPIN/SAMIP (2014), „Social Assistance and Minimum Income Protection Interim Dataset", www.spin.su.se/datasets/samip (accessed 3. January 2017) Tomka Béla (2015), Szociálpolitika - Fejlödés, formák, összehasonlitások [Social Policy - Development, Forms and Comparisons], Budapest, Osiris Zombori Gyula (1994), A szociálpolitika alapfogalmai [The Basics of Social Policy], Budapest, Hilscher Rezső Szociálpolitikai Egyesület 
